\title{
Fostering Stakeholder Engagement through Companies’ Website: A Comparison between Sector
}

\author{
Eva Cerioni ${ }^{1}$ \\ ${ }^{1}$ Department of Management, Università Politecnica delle Marche, Ancona, Italy \\ Correspondence: Eva Cerioni, Department of Management, Università Politecnica delle Marche, Piazzale \\ Martelli, 8-60121 - Ancona, Italy. E-mail: e.cerioni@staff.univpm.it
}

Received: November 24, 2020

Accepted: January 23, 2021

Online Published: January 30, 2021

doi:10.5539/ijbm.v16n2p96

URL: https://doi.org/10.5539/ijbm.v16n2p96

\begin{abstract}
During the years, different authors underline the role of CSR communication as an instrument of transparency towards the stakeholders of each company. In the scenario emerge the importance of stakeholder engagement for estabilish between company and stakeholders "proactive and ongoing dialogue", trough Internet and it's tools as a facilitator of corporate communicative action. With the aim of communicating with the stakeholders, companies can implement different methods of engagement. Operating in different sectors many time it is an additional variable that influences the practice of CSR communication, will it be the same for the stakeholder engagement methods adopted? This contribution analyses, through a content analysis, all the stakeholder engagement tools used by the 316 companies listed in DJSI on their institutional websites. The DJSI companies are strongly motivated to commit in economic, social and environmental terms and belonging to 24 different sectors thus allowing to carry out inter-sectoral analyzes. There are two main results: prevailing use of one-way communication tools regardless of the sector of the company and a widespread choice to use social media as the main two-way communication tool. If the sector of belonging, in other study has turned out to be an influential variable, the same cannot be said in relation to stakeholder engagement tools. This study has three main limitations: data change speed, language and method. In the future, understanding the expectations and needs of stakeholders related to CSR communication could be intersting to analyse.
\end{abstract}

Keywords: stakeholder engagement, CSR communication, internet, digital tools

\section{Introduction}

Corporate Social Responsibility (CSR) has undergone a huge evolution over time: both doctrine and practice have, in fact, proposed a plethora of definitions, tools, and techniques that have followed one another over the years. Almost every modern organization is in one way or another involved in CSR activities (De Jong \& Der Meer, 2017). As recognized by Schoeneborn, Morsing, and Crane (2020) through CSR communication CSR practices can become "talked into being" (p. 7). Several authors and organizatioans (as Corporate Sustainability Assessment of SAM) stress the role of CSR communication based on two key words: transparency and dialogue with stakeholders (Kim, 2014; Kim \& Ferguson, 2018; Lim \& Greenwood, 2017; Yekini et al., 2019; Seele \& Lock, 2014).

In this scenario emerges the importance of companies to establish a "proactive and continuous dialogue" (Morsing \& Schultz, 2006) with its stakeholders. Stakeholder questions to companies range from ways of resolving the criticalities encountered by the company up to knowledge of performance in all its dimensions (economic, social and environmental) (Thomson \& Bebbington, 2005). The practice of stakeholder engagement is in fact becoming a real strategy of companies that try to anticipate all the probable demands and needs of stakeholders (Pucheta-Martínez \& Gallego-Álvarez, 2020).

The communication of performance in its three-dimensional ignition (economic, social and environmental) to all stakeholders, is one of the key points of CSR. Clearly, therefore, the importance of communication and dialogue with stakeholders, each company will seek to use all available technologies to achieve this objective (ISO-OECD, 2017).

With the aim of communicating with the stakeholders, companies can implement different methods of engagement including: surveys, brochures, forums / workshops, social channels and others (Adams \& Frost, 
2006; Li \& Li, 2014; Owen et al., 2001; Swift, 2001; Thomson \& Bebbington, 2005; Unerman \& Bennett, 2004). But it is clear from literature and practice that trough Internet is easily, quickly and cheaply allows companies to communicate with their stakeholders (Adams \& Frost, 2006; Correa-Garcia et al., 2018; Guillamón-Saorín \& Martínez-López, 2013; Lodhia \& Stone, 2017; Nelson, 2019). Some autors underlined the internet potential to establish a two-way communication and foster a dialogue with stakeholders on CSR topics (Esrock, \& Leichty, 1998; Unerman, \& Bennett, 2004). But few studies focues on the use of CSR communication channles in different industry sector. This paper addresses the main question as whether CSR information disclosure on corporate websites is different inter-sector?

Operating in different sectors many time it is an additional variable that influences the practice of CSR communication. The precedent studies highlighted a significant variability in the type and level of social and environmental information, as well as economic, by companies operating in the different industry (Brammer \& Pavelin, 2006; Bozzolan, O'Regan \&Ricceri, 2006) but few authors focused on the difference of CSR communication tool inter-sector. Only some scholars have showed that the companies belonging to the services sector appear less interested in responding to expectations of what may be relevant for stakeholders and disclose less accurate information; while companies that produce and trade energy resources tend to greater transparency and compliance with sustainability reporting standards, given the pressure to which they are subjected by institutions, activists, customers, in demonstrating their socially responsible behavior towards the protection of resources natural (Torelli, Balluchi \& Furlotti, 2019).

In this field, the paper aims to empirically investigate the use of stakeholder engagement method in particular the Internet- based tool by the listed companies of the DJS index. The research questions are "Which method of engagement DJSI companies use? Is the choice of method different between sectors?".

This contribution analyses, through a content analysis, all the stakeholder engagement tools used by the 316 companies listed in DJSI on their institutional websites. The objective of this study is to exposes this centrality by throwing light to the extent to which the DJSI companies is using the communicative capabilities of the Internet to develop innovative stakeholder engagement initiatives. The paper is structured as follow: the CSR background, the method, and finally, the results are discussed, underlining the limitation of the study.

\section{Background}

Corporate social responsibility (CSR) has become a frequent topic of discussion and research. The United Nation underlined the relevance of CSR communication by organizations and declared that the "communication can take a variety of forms with affected stakeholders, and formal public reports" (United Nation, 2011, p. 24). In this scenario emerge the importance to engage the stakeholders in dialogue trought the use a variety of method of engagement, like: internet, bulleting and letters, surveys, focus groups, media and many others (AA1000 Standard, 2015).

Stakeholders are "any group or individual who can effect, or is affected by, the achievement of a corporation's purpose" (Freeman, 1984, p. vi). Social accounting information allow users (stakeholders) to assess whether the entity is socially, financially and environmentally responsible (Gray \& Guthrie, 2007, p. 23). Stakeholder engagement is an important part of good business practice and may prove helpful in managing risks successfully and enhancing stakeholder benefits (Pucheta-Martínez et al. 2020, p. 2).

Over time, different classifications of the method of engagement stakeholders emerge from the literature. Morsing and Schultz (2006) argue that depending on the way in which stakeholders are involved, the dialogue is diversified into: information strategy for stakeholders; stakeholder response strategy; and stakeholder engagement strategy. Inspired by Habermas' theory of ethical discourse (1990), Seele and Lock (2014) classify the communication tools of CSR in: instrumental (corporate) or deliberative and published or unpublished. Recently the AA1000 Stakeholder Engagement Standard (2015) states that there are two levels of engagement: those that allow one-way communication and those that favor two-way engagement (Kim, 2014; Morsing \& Schultz, 2006; Seele \& Lock, 2014). With regard to this last category, the OECD has recognized the potential of two-way communication tools to allow for "effective involvement of interested parties" (OECD, 2017, p. 29). The medium that today allows companies to disseminate the greatest amount of information at low cost (Jose and Lee, 2007; Ha and James, 1998; Wanderley et al., 2008) is: Internet. This tool is increasingly used also specifically for information relating to the CSR theme as it allows for dialogue with interested parties (Esrock, \& Leichty, 1998; Unerman, \& Bennett, 2004). Companies have noted that thanks to the Internet they have the possibility to: redefine stakeholder expectations and not just collect information (Bonsón \& Ratkai, 2013), interact with stakeholders and differentiate and personalize messages, based on their information needs (Adams, \& Frost, 2006; Wheeler, \& Elkington, 2001). But few and not recently studies have shown that there are several 
variables (such as size, sector and country) that can impact CSR activities on the website (Frostenson et al., 2011; Tagesson et al., 2009; Tetrevova et al., 2019; Wanderley et al., 2008). It is important to investigate whether there are differences between industry sector regarding stakeholder engagement through corporate websites.

There are other studied that shown a significant variability in the type and level of social and environmental information, as well as economic, by companies operating in the different industry (Brammer \& Pavelin, 2006; Bozzolan, O'Regan \&Ricceri, 2006). For example, companies with a high environmental impact tend more to publish non-financial information (Brammer \& Pavelin, 2008; Gamerschlag et al., 2011; Young \& Marais, 2012) and also companies that carry out high-risk environmental activities (for example: energy, transport, infrastructure, chemicals, construction, mining and industrial) are more inclined to disclosure its environmental performances (Deegan \& Gordon, 1996; Haddock-Fraser \& Tourelle, 2010; Hassan \& Ibrahim, 2012; Patten, 2002). Some scholars have highlighted that the companies belonging to the services sector appear less interested in responding to expectations of what may be relevant for stakeholders and disclose less accurate information; while companies that produce and trade energy resources tend to greater transparency and compliance with sustainability reporting standards, given the pressure to which they are subjected by institutions, activists, customers, in demonstrating their socially responsible behavior towards the protection of resources natural (Torelli, Balluchi \& Furlotti, 2019). In this study the focus is on the different approach to CSR communication tools by companies from different sectors.

\section{Method}

The purpose of this study is to analyse the use of internet-based CSR information communication tools by DJSI listed companies. It was chosen to take as sample analysis the DJSI companies because: provides for the presence of companies not only strongly motivated to commit in economic, social and environmental terms (Hawn et al., 2018) but also belonging to 24 different sectors (figure 1) thus allowing to carry out inter-sectoral analyzes.

The decision to focus on Internet tools is due to the potential stated by previous studies of this medium as a means of direct communication to ensure transparency (among others, Frost et al., 2005; Patten, 2002; Patten \& Crampton, 2004; Williams \& Pei, 1999).

Of the 317 listed companies of DJSI (full list available on SAM), 46\% are European, 26\% Asian, 22\% American, $5 \%$ Australian and the remaining 1\% African. Several sectors are included in the sample: Capital goods (10.4\%), banking $(8.5 \%)$, materials $(7.6 \%)$, real estate $(6.5 \%)$, software and services $(5.4 \%)$.

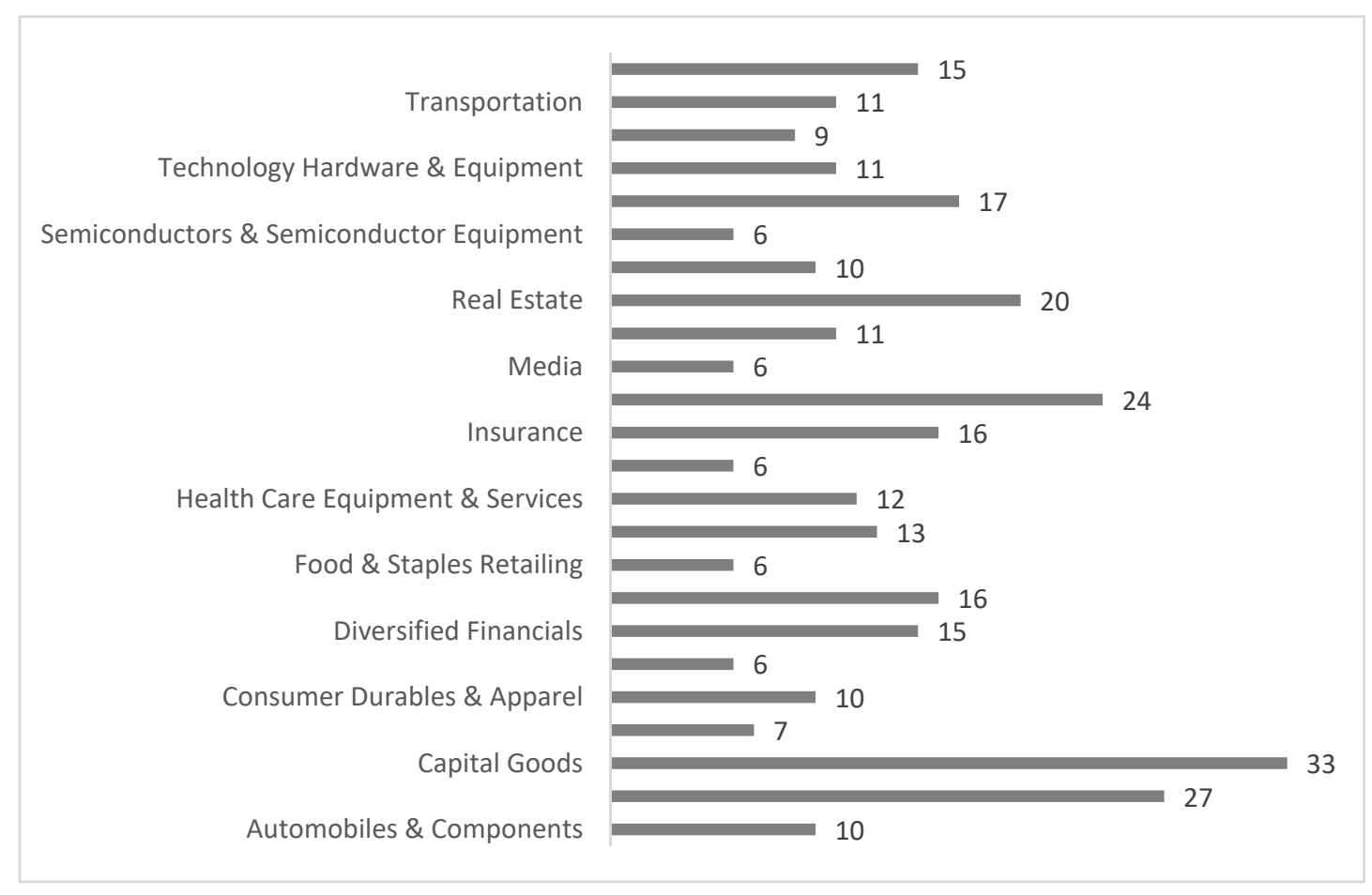

Figure 1. DJSI listed companies by industry groups 
In order to answer the search question, a content analysis (Krippendorff, 2018) was carried out on the company websites of the 316 listed companies of DJSI (one company does not have access to the institutional website). This method has been used by other authors in the past to analyse and compare the websites of a sample of companies by examining their CSR activities (Basil \& Erlandson, 2008) and style of presentation sites to communicate CSR (Chaudhri \& Wang's, 2007; ADI \& Grigore, 2015). Content analysis mainly helps to organise information in such a way as to simplify data analysis and interpretation of results (Singh, 2020). Content analysis, used as a research technique to make reproducible and valid deductions from data into their context" (Krippendorff, 2018). The application of this method requires a rigorous analysis that follows strict rules on which data to collect and how to encode and measure it (Milne \& Adler, 1999). For all companies, the relevant dimension of CSR (Siano et al., 2016) was sought on the company websites, by assigning "Yes" or "No". The "search" tool of each website is used with keywords representing the different relevant dimensions that are: CSR section, CSR report, General contact (mail/form), FAQ about CSR, CSR specfic e-mail/form, questionnaire, forum $/ \mathrm{blog}$, report on meetings and consultations, stakeholder engagement dedicated section and news section. The analysis is started from the home page of the company's website. Secondly, sections on stakeholder engagement and corporate social responsibility are analysed (if available). All the website have been carefully analysed following the same rules and annotating the data deriving from the analysis on an encoding sheet on Excel so that you can then verify and reprocess the collected data.

\section{Results}

To answer research questions this study investigates one-way and two-way published communication tools by DJSI companies through Internet. According to the AA Stakehodlder engagement Standard (2015) classification, I explored the organizations which are using internet-based tools as method of stakeholder engagement on CRS issues. For some companies the web page does not work, or no English language is used, so in this cases "not accessible" is indicated.

\subsection{One-Way Communication Tools}

The Figure 2 shows the use of the one-way communication tools by DJSI listed companies. These tools provide for the company's communication to its stakeholders without any feedback from them. In this category of tools, this study includes: CSR section; News Section, CSR report, reports on meetings and/or consultations, accessibility issues and frequently asked questions (FAQs).

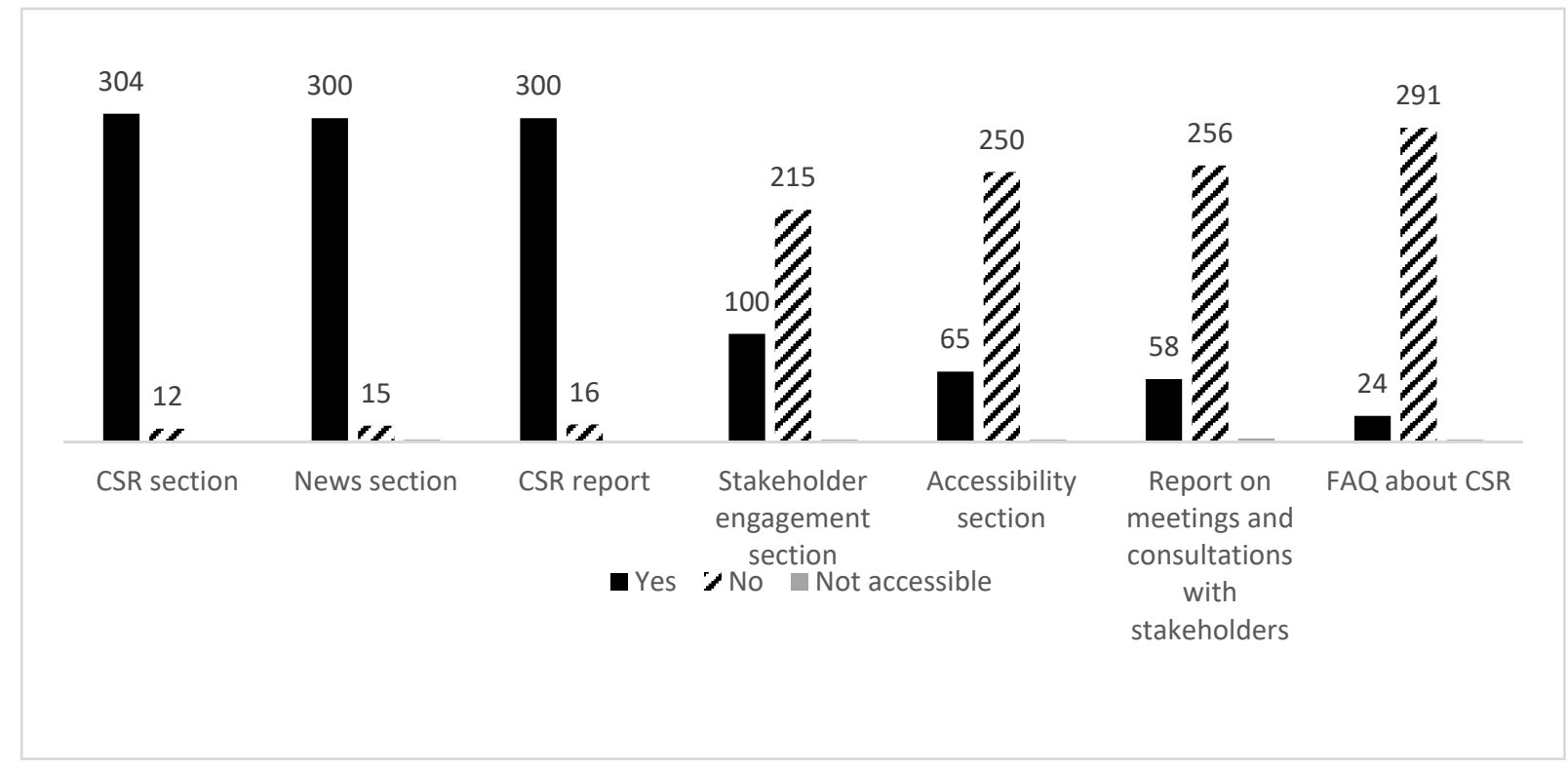

Figure 2. One - way published communication tools used by DJSI listed companies

From the analysis of the figure 2 it emerges clearly that over $95 \%$ of the companies include in their web-site a CSR section and a News section to inform stakeholder about their CSR initiatives. The use of other tools is much less widespread: stakeholder engagemenr section (32\%), accessibility section (21\%), report on meetings and 
consulations with stakeholders (18\%) and FAQ about CSR (8\%).

After making a macro analysis of the one-way communication tool, a focused analysis is carried out for each industry sector of its membership.

Of all the sample, $96 \%$ of companies have a section of the website dedicated to CSR but with different names ("sustainability", or "our responsability"). All sectors of the DJSI sample welcome this choice with high percentages to devote a section to CSR acknowledging its importance. The lowest percentage is found in the Insurance sector while recording a presence of $81 \%$ of companies with dedicated CSR.

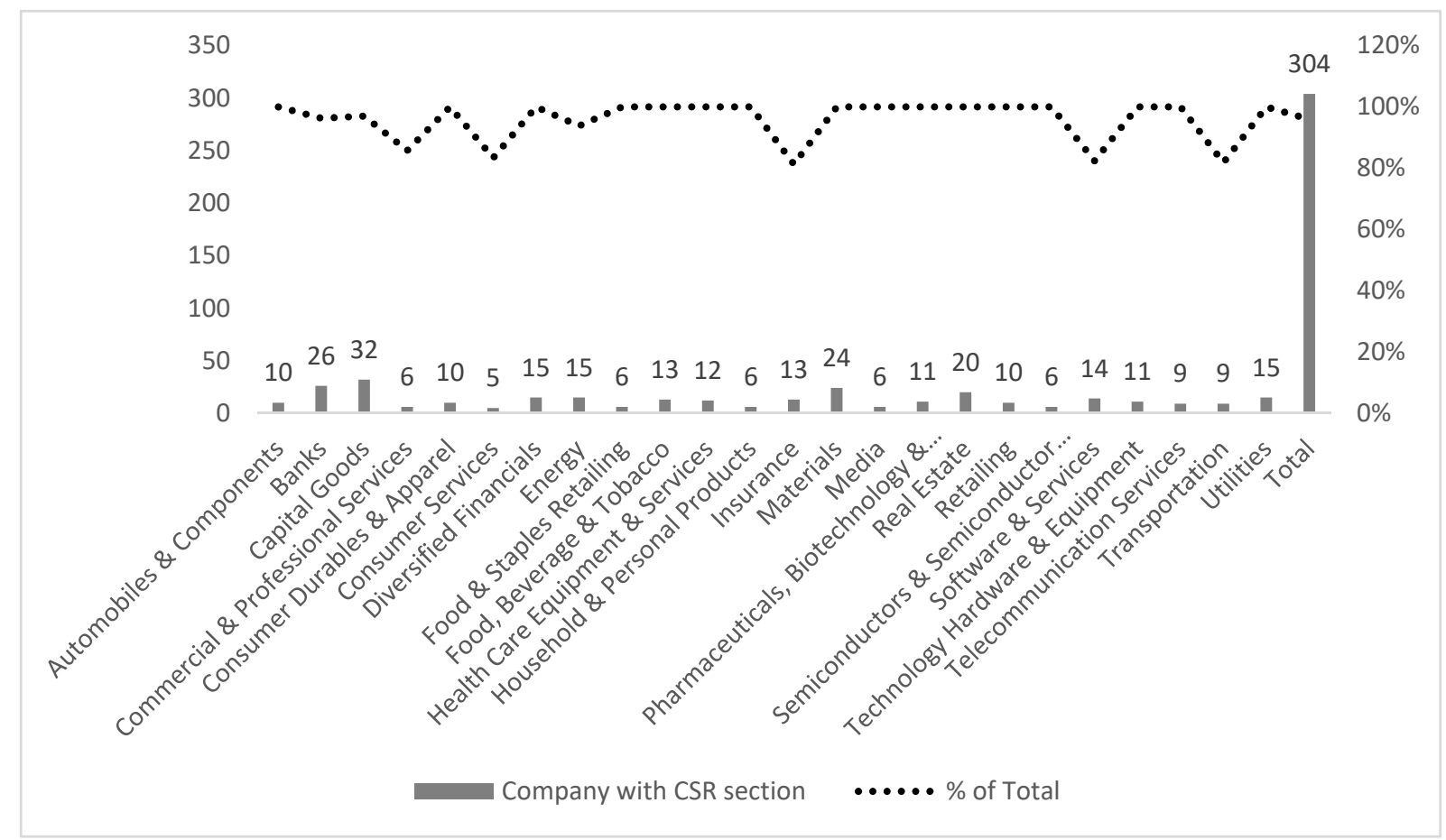

Figure 3. Sectors of companies that have the CSR section

In relation to CSR report 300 of the DJSI companies published this accountability tool. About $30 \%$ of them have a specific space dedicated to a stakeholder engagement section. Among these, $84 \%$ of the companies published Sustainability Report following Global Reporting Initiative Guidelines (GRI) and 8\% of the companies published Integrated Report following International Integrated Reporting Council Framework (IIRC). One italian company publish a document called "Dichiarazione non finanziaria - DNF". The other companies publish the annual report where thery are inclueded non-financial information. At the sectoral level, again the sector less prone to publish CSR reports is Insurance with $75 \%$. The details are given in Table 1.

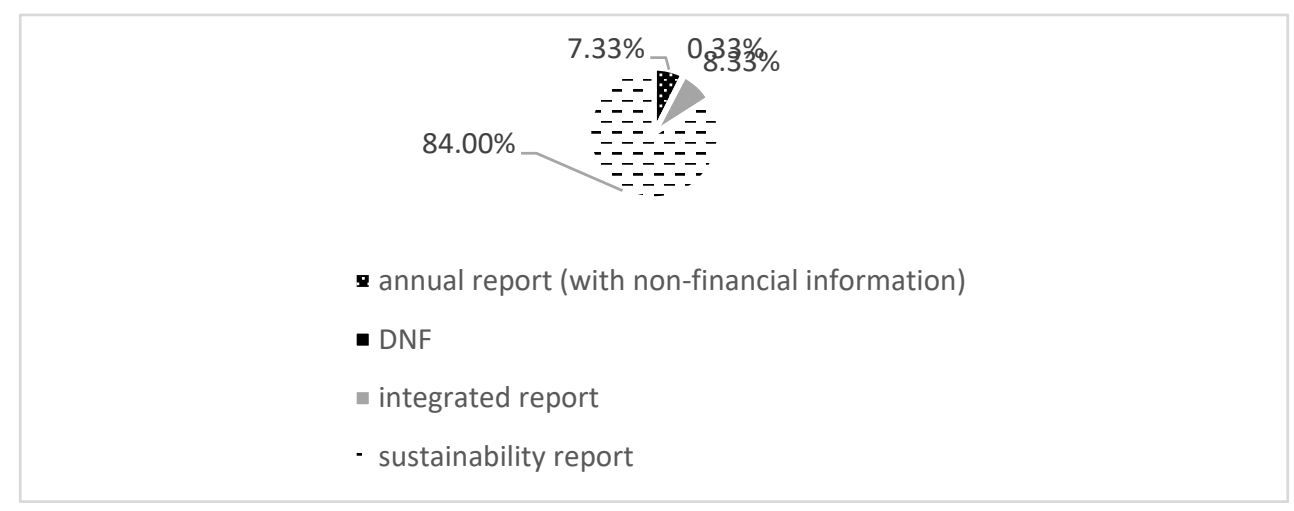

Figure 4. Type of CSR report 
Table 1. Sectors of companies publish CSR report

\begin{tabular}{|c|c|c|}
\hline Industry Group & Company with CSR report & $\%$ of Total \\
\hline Automobiles \& Components & 10 & $100 \%$ \\
\hline Banks & 27 & $100 \%$ \\
\hline Capital Goods & 33 & $100 \%$ \\
\hline Commercial \& Professional Services & 6 & $86 \%$ \\
\hline Consumer Durables \& Apparel & 10 & $100 \%$ \\
\hline Consumer Services & 5 & $83 \%$ \\
\hline Diversified Financials & 15 & $100 \%$ \\
\hline Energy & 16 & $100 \%$ \\
\hline Food \& Staples Retailing & 6 & $100 \%$ \\
\hline Food, Beverage \& Tobacco & 13 & $100 \%$ \\
\hline Health Care Equipment \& Services & 12 & $100 \%$ \\
\hline Household \& Personal Products & 6 & $100 \%$ \\
\hline Insurance & 12 & $75 \%$ \\
\hline Materials & 23 & $96 \%$ \\
\hline Media & 6 & $100 \%$ \\
\hline Pharmaceuticals, Biotechnology \& Life Sciences & 10 & $91 \%$ \\
\hline Real Estate & 20 & $100 \%$ \\
\hline Retailing & 10 & $100 \%$ \\
\hline Semiconductors \& Semiconductor Equipment & 6 & $100 \%$ \\
\hline Software \& Services & 15 & $88 \%$ \\
\hline Technology Hardware \& Equipment & 10 & $91 \%$ \\
\hline Telecommunication Services & 8 & $89 \%$ \\
\hline Transportation & 9 & $82 \%$ \\
\hline Utilities & 12 & $80 \%$ \\
\hline Total & 300 & $95 \%$ \\
\hline
\end{tabular}

Similar considerations are found for the presence of sections dedicated to News ( $94.64 \%$ of total companies). In this case, the sector with the lowest percentage (50\%) of this instrument's presence is the Media sector. Paradoxically, perhaps due to the use of other types of tools to communicate new ones to its stakeholders. Then follows the Pharmaceuticals, Biotechnology \& Life Sciences sector with 73\%. But always acknowledging high adherence values. 


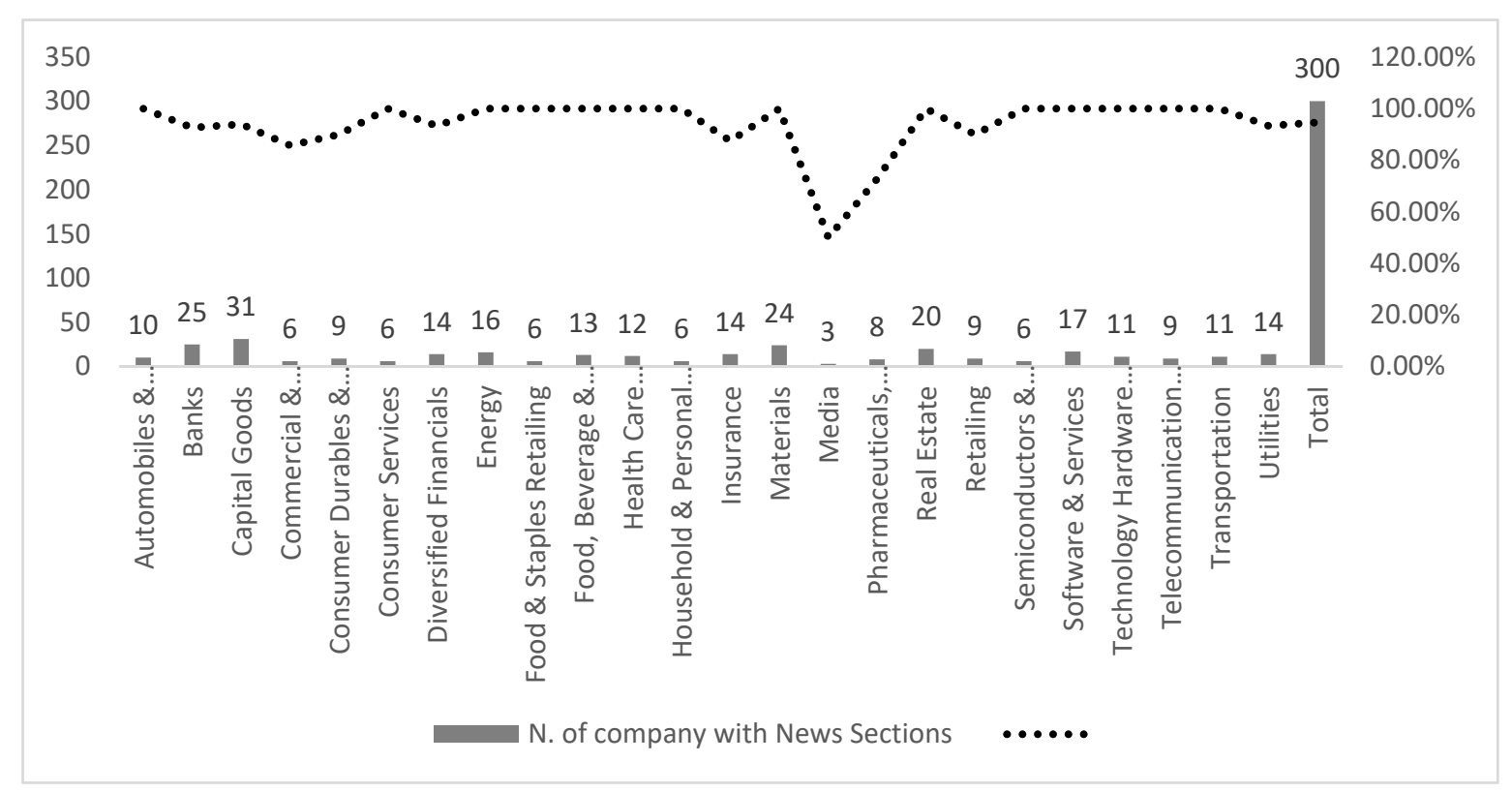

Figure 5. Sectors of companies that have News section

Significantly lower percentages are recorded in relation to the presence of a section dedicated to stakeholder engagement equal to $32 \%$ of all the companies in the sample. The two sectors where the companies that choose to devote a section to dialogue with stakeholders are very few are that of Pharmaceuticals, Biotechnology \& Life Sciences (9\%) and Software \& Services (12\%).

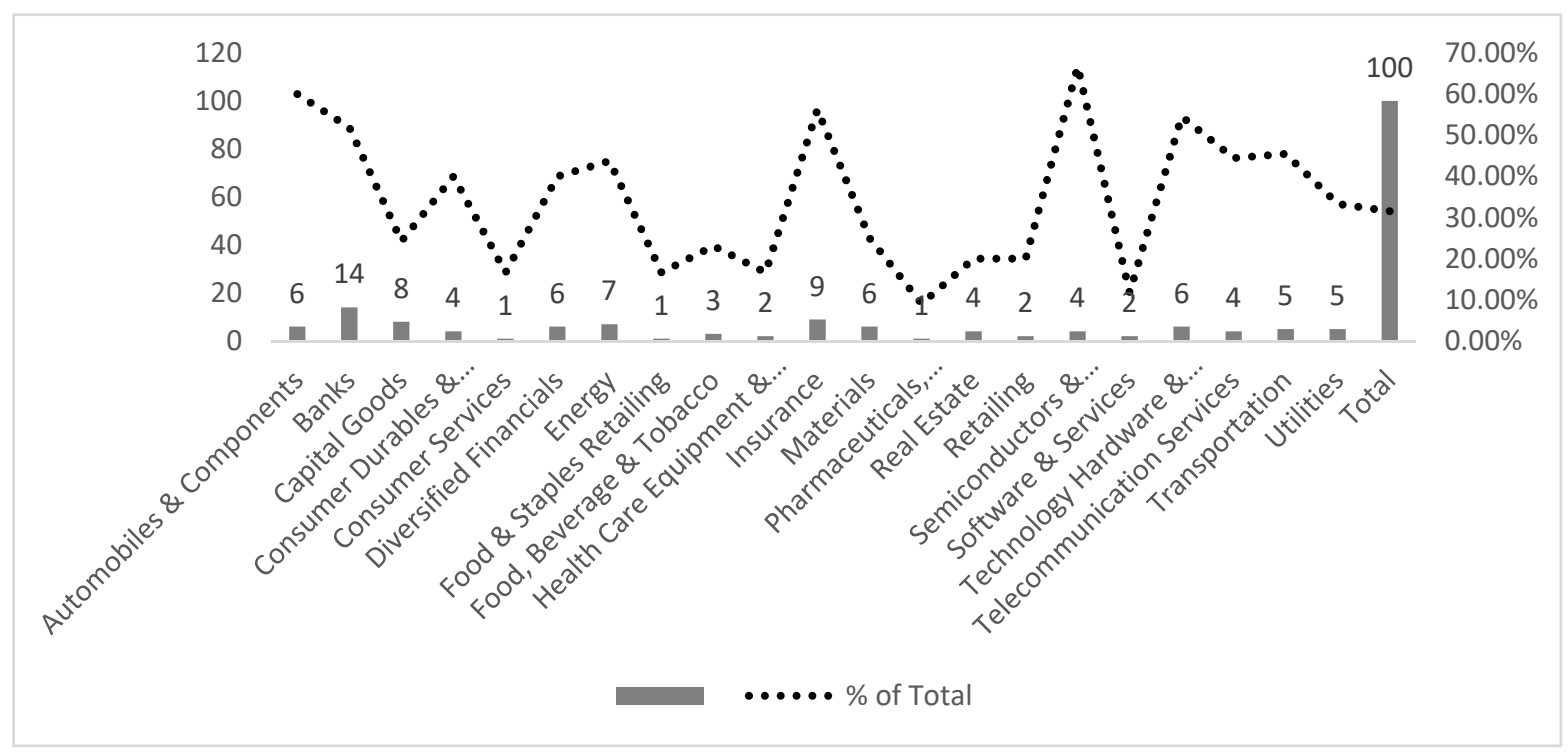

Figure 6. Sectors of companies that have SE section

It then goes on to analyse the last three tools: Accountability section, report on meetings and consultations and FAQ about CSR. All three have low levels of feedback between organizations.

Accessibility provides for the presence of a simple and immediate interface of websites without discriminating against users depending on the access tool they use. In this respect, only 65 companies showed visibility statements on the home page with a specific focus on the access key. The use of the accessibility section is $20 \%$ of the farm sample. This choice is shared by almost all sectors except in the insurance and retailing sector where the share is more than $40 \%$. Only $18 \%$ of DJSI companies upload to their website, such as stakeholder engagement tools, reports on meetings and stakeholder consultations, or other reports on different business 
issues.

Again, the sector which deviates the most from the general figure is Insurance, with $44 \%$ adherence to it, followed by Retailing (40\%). Finally, even less use is made of the FAQs for CSR, which in general was adopted by only $7 \%$ of the companies in the sample. FAQs are answers to questions which it is taking to have been fortified by an interested party. In this case, no sector records data other than general data.

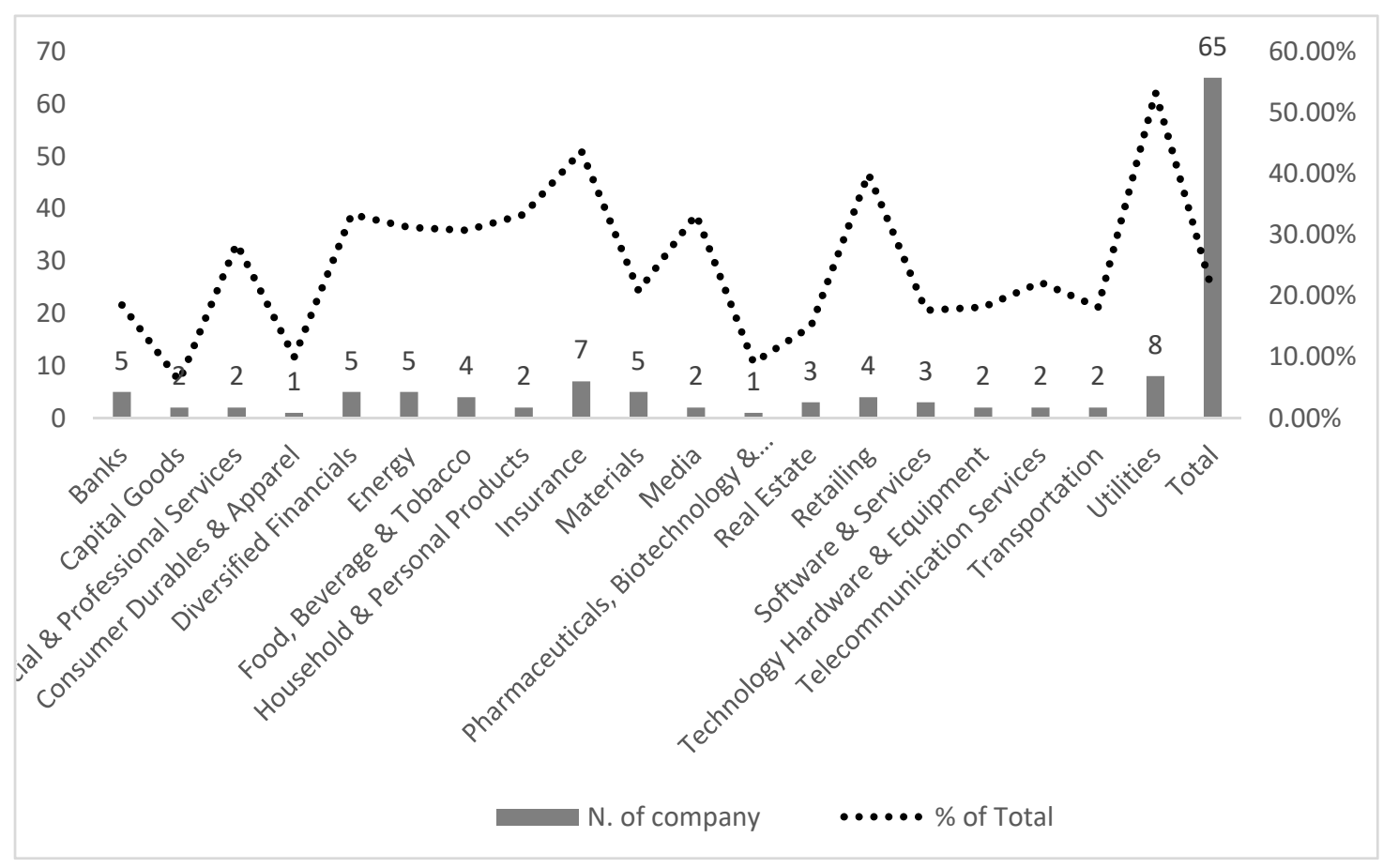

Figure 7. Sectors of companies that have accessibility section

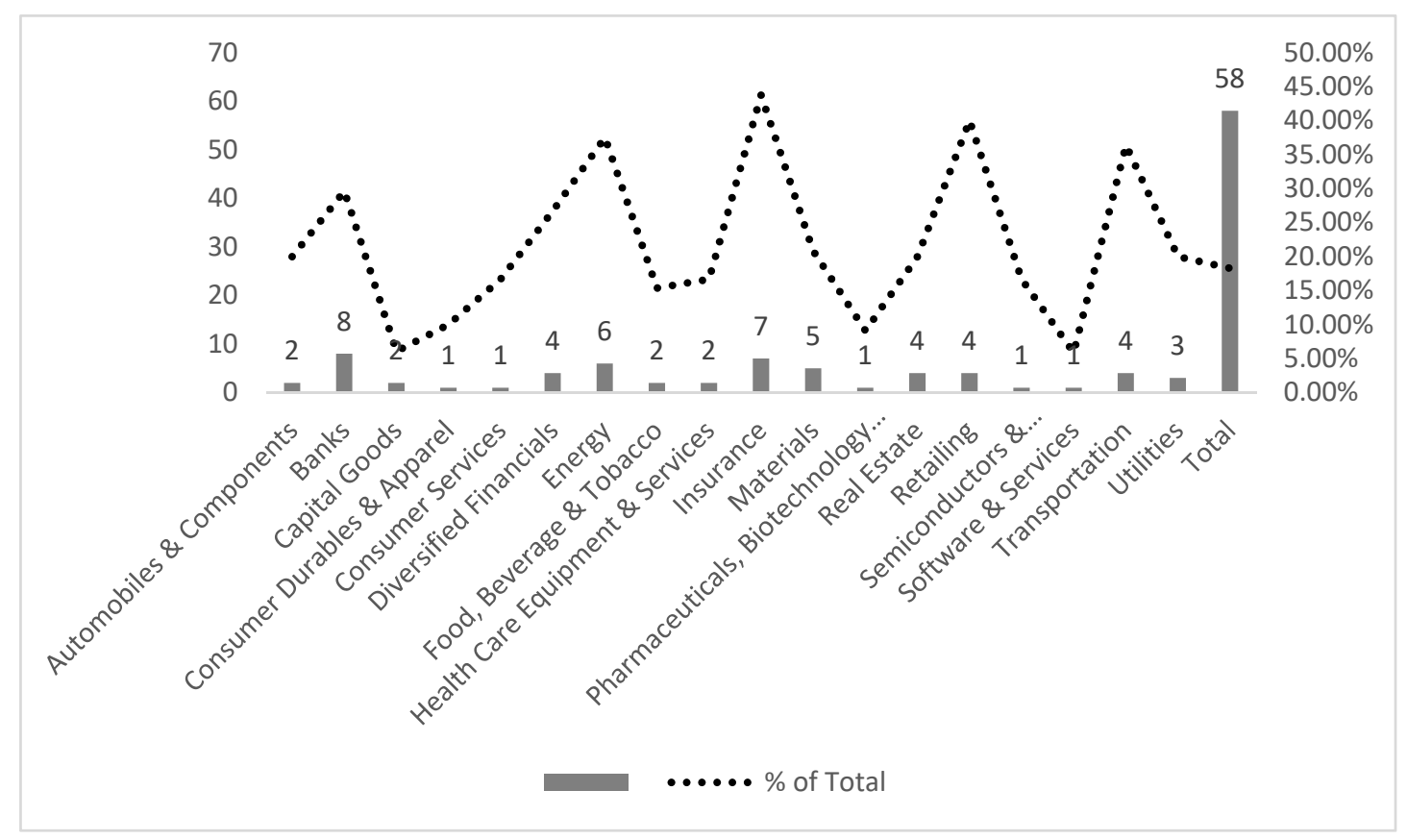

Figure 8. Sectors of companies published report on meetings and consultations 


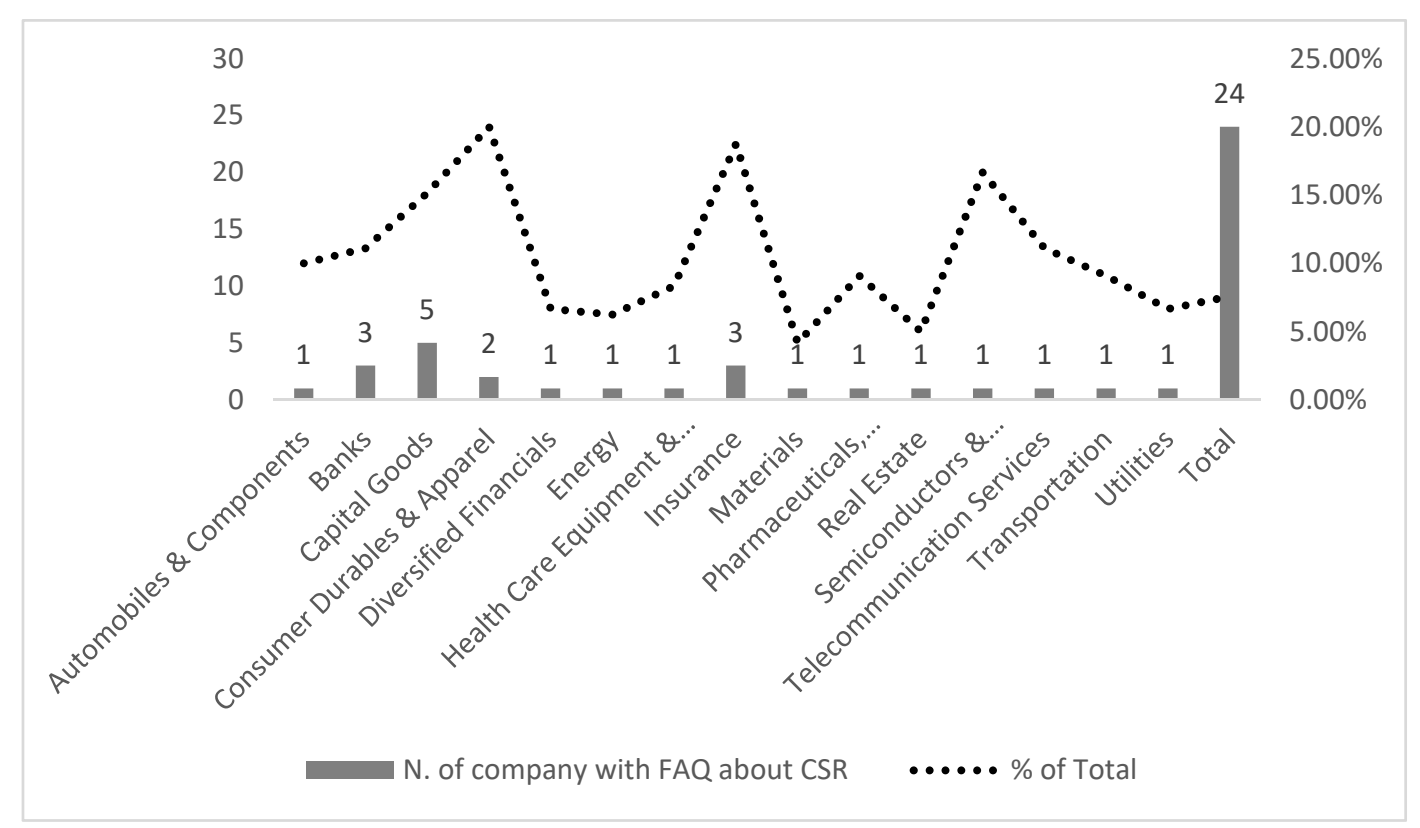

Figure 9. Sectors of companies published FAQ about CSR in website

\subsection{Two-Way Communication Tools}

The two-way published communication are divided in two type: tools based on a two-way dialogue, such as blogs / forums and social media, and tools with less interactivity with stakeholders such as emails / forms, online questionnaires and surveys. In particular, the two-way communication tools "trying to get feedback from a number of stakeholders, or even to engage interested parties" (Isenmann, 2006).

As shown by data (see Figure 10), email or web form as well as social media are adopted by more than $80 \%$ of the DJSI companies, whereas forum/blog and questionnaire are used by less then $10 \%$ of the organizations. Despite this, the use of two-way communications tools appears lower than the instrumental tools.

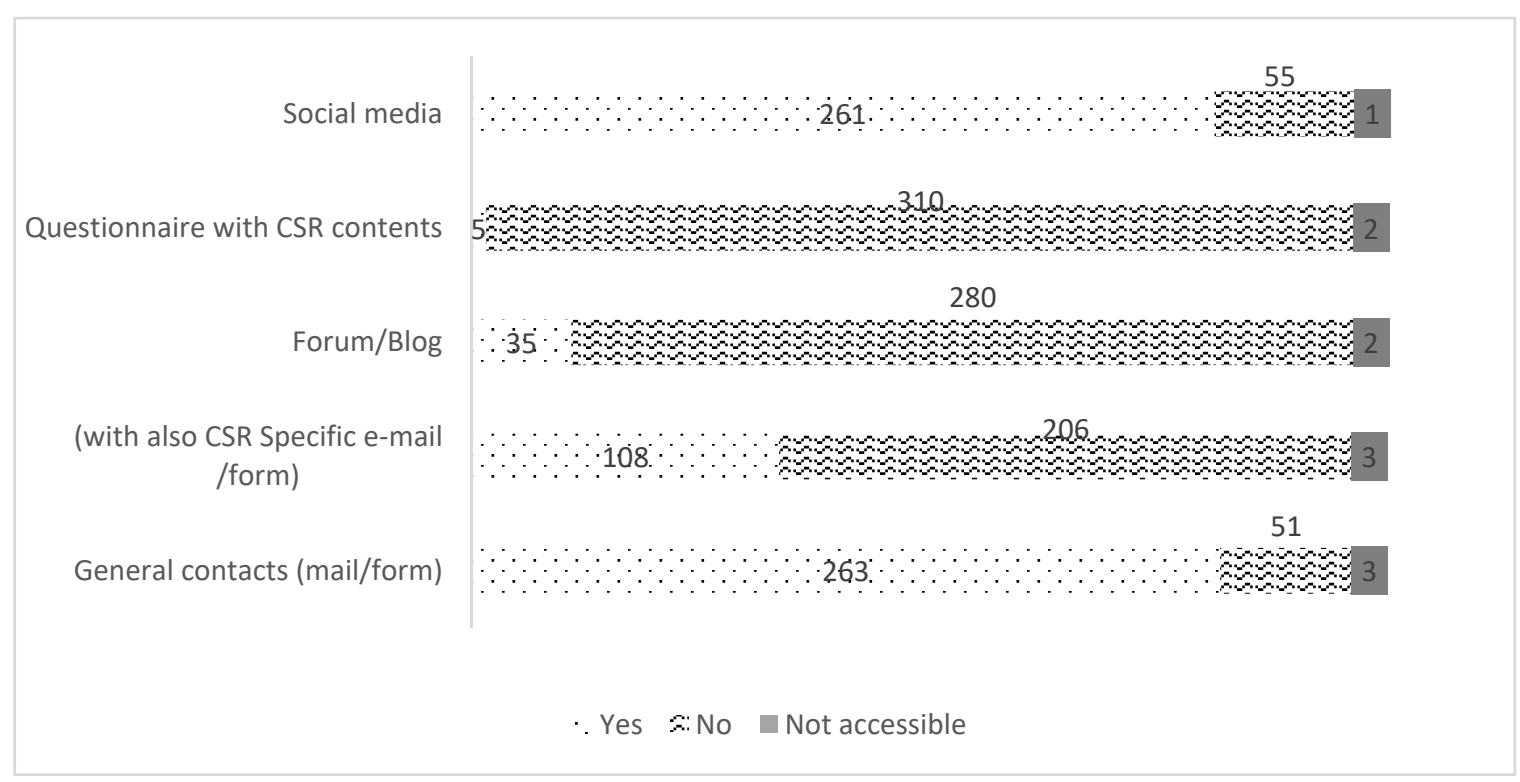

Figure 10. Two-way published communication tools used by DJSI listed companies

From a first overview e-mails or, alternatively, web forms (of which $41 \%$ dedicated specifically to CSR topics) 
are the most used tools to engage stakeholders ( $83 \%$ ). Only 35 companies implemented forums and blogs. It was found that feedback questionnaires are used by only $1,5 \%$ of the DJSI listed companies. The last focus in on social media used by 261 companies and it is a good results.

The analysis is then carried out at sectoral level. The analysis underlines that 122 of the websites have adopted e-mail, while 113 have used web modules capable of delivering a message directly to the web page and 28 have chosen both (the rest chooses only physical address and/or phone number).

However regard the e-mails all sectors have liena percentages with the sample $(38 \%)$ except higher peaks reached by the Car sector, Real summer, Retailing with $60 \%$ and the Semiconductors \& Semiconductor Equipment sector with $67 \%$. The lowest peaks are recorded for Utilities (12\%) and Commercial \& Professional Services $(13 \%)$. For the form, the sector which deviates positively from the overall figure is the Consumer durables \& Apparel sector with $60 \%$, while the Diversified Financials sector (13\%) is negatively affected. They claim to use both e-mails and $8 \%$ of the sampled companies mainly in the Household \& Personal Products sector, as $50 \%$ of all companies in that sector have both tools.

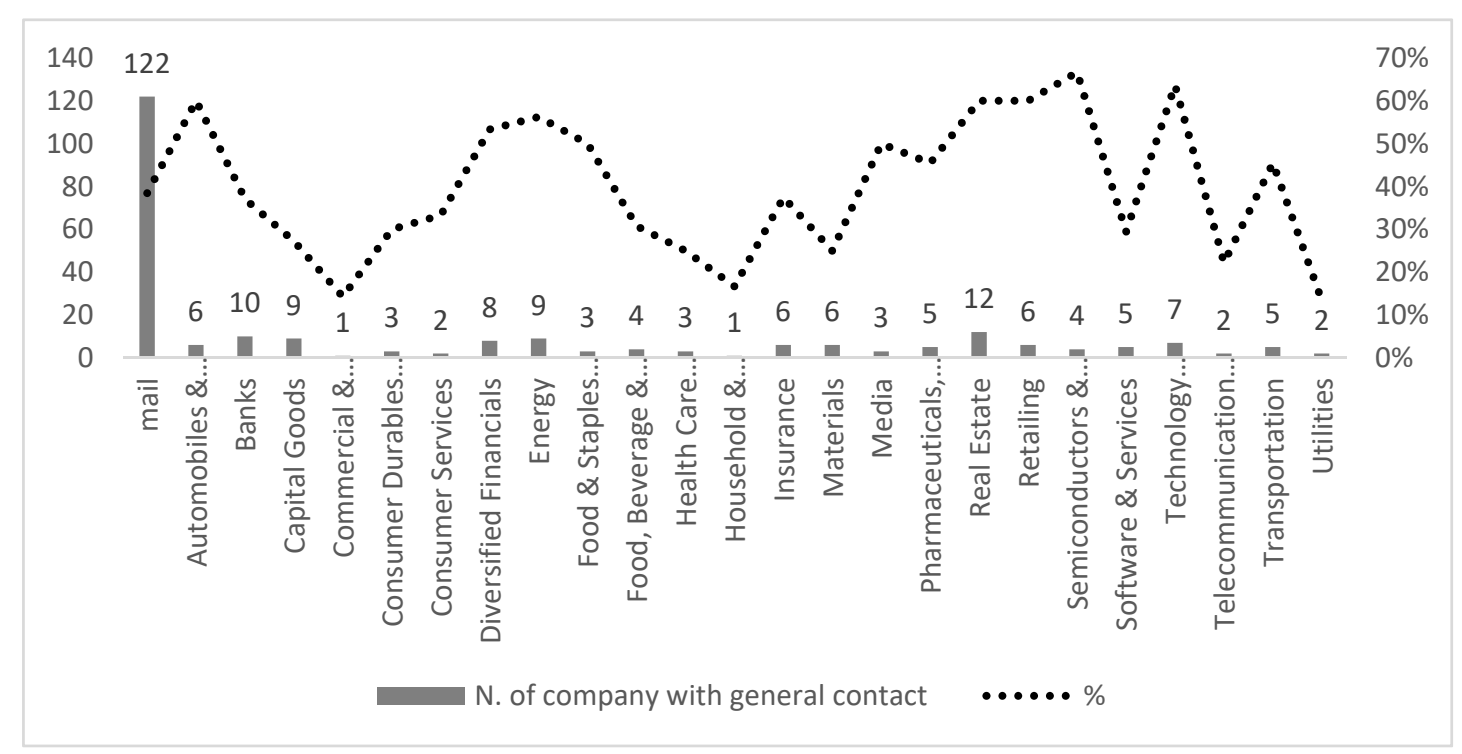

Figure 11. Sectors of companies published General contract in website: e-mail

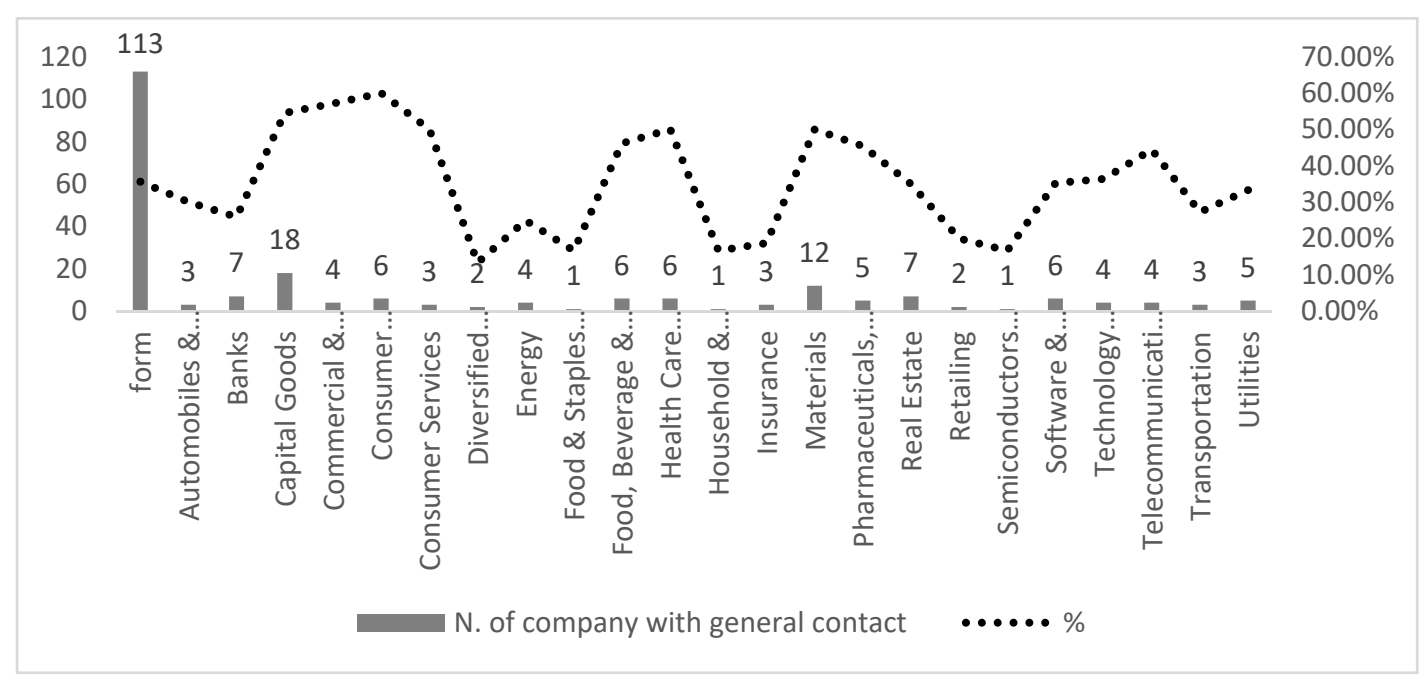

Figure 12. Sectors of companies published General contract in website: form 


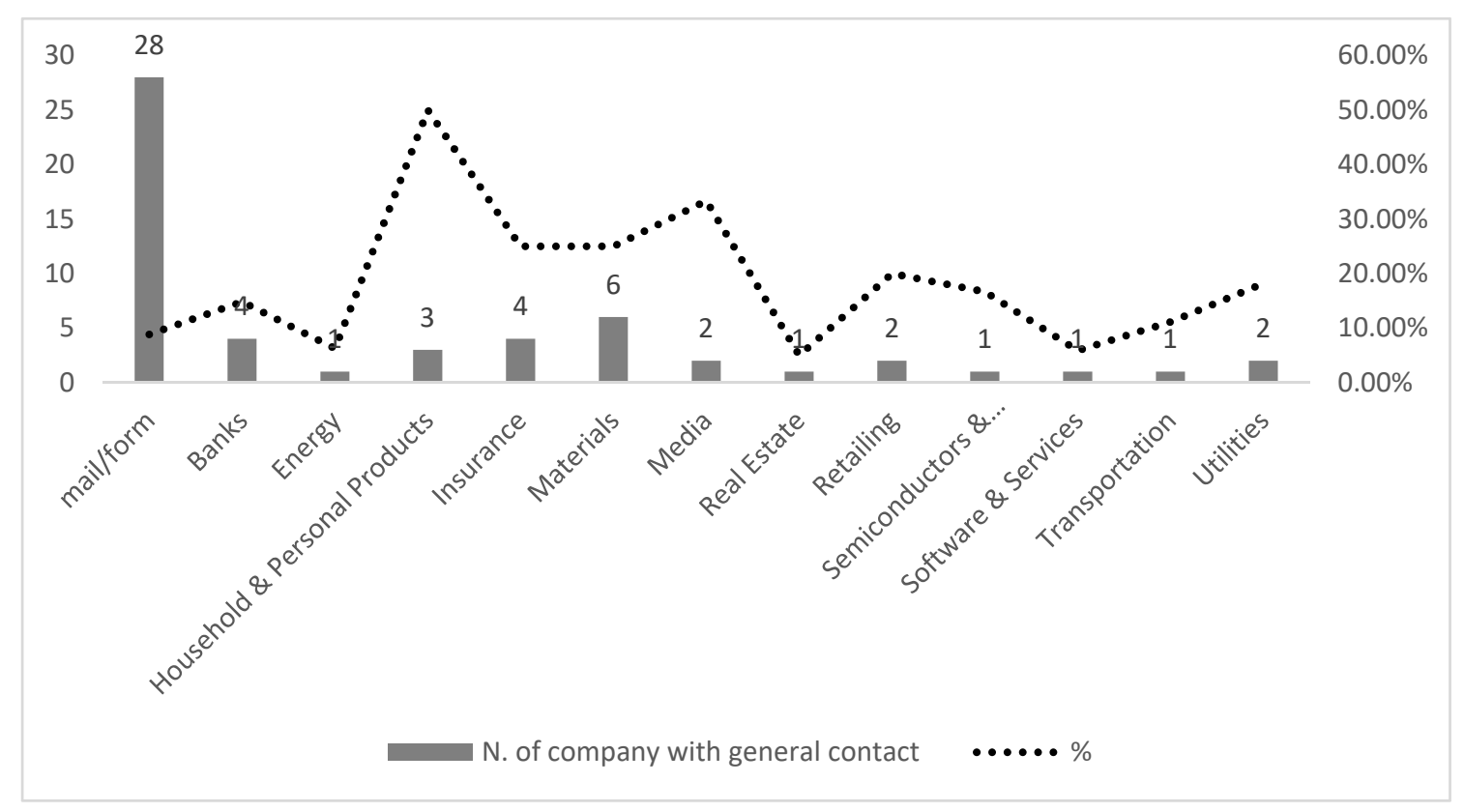

Figure 13. Sectors of companies published General contract in website: mail/form

On the other hand, looking at the presence of e-mails and forms specifically dedicated to CSR, the figure decreases significantly to $34 \%$ of the total. In this case, the Retailing and Insurance sectors have doubled the overall sample by $60 \%$. Telecommunication Services and Real Estate sector only have CSR e-mails and forms for $10 \%$ of the sample.

Table 2. Sectors of companies with specific e-mail/form

\begin{tabular}{lll}
\hline Industry Group & N. of company with Specific E-mail/form & \% of Total \\
\hline Automobiles \& Components & 3 & $30,00 \%$ \\
Banks & 7 & $25,93 \%$ \\
Capital Goods & 14 & $42,42 \%$ \\
Commercial \& Professional Services & 3 & $42,86 \%$ \\
Consumer Durables \& Apparel & 5 & $50,00 \%$ \\
Consumer Services & 1 & $16,67 \%$ \\
Diversified Financials & 5 & $33,33 \%$ \\
Energy & 8 & $50,00 \%$ \\
Food \& Staples Retailing & 1 & $16,67 \%$ \\
Food, Beverage \& Tobacco & 4 & $30,77 \%$ \\
Health Care Equipment \& Services & 3 & $25,00 \%$ \\
Household \& Personal Products & 2 & $33,33 \%$ \\
Insurance & 9 & $56,25 \%$ \\
Materials & 14 & $58,33 \%$ \\
Media & 3 & $50,00 \%$ \\
Pharmaceuticals, Biotechnology \& Life Sciences & 2 & $18,18 \%$ \\
Real Estate & 2 & $10,00 \%$ \\
Retailing & 6 & $60,00 \%$ \\
Semiconductors \& Semiconductor Equipment & 3 & $50,00 \%$ \\
Software \& Services & 3 & $17,65 \%$ \\
Technology Hardware \& Equipment & 4 & $36,36 \%$ \\
Telecommunication Services & 1 & $11,11 \%$ \\
Transportation & 3 & $27,27 \%$ \\
Utilities & 2 & $13,33 \%$ \\
Total & $\mathbf{1 0 8}$ & $\mathbf{3 4 , 0 7 \%}$ \\
\hline
\end{tabular}


As regards the presence of specific questionnaires on companies' websites, it is clear that this is not a tool used and a maximum of $12 \%$ of the total companies in the insurance sector make use of them. The results for the forum and blog tool are slightly higher and in the past they were widely used, while analysis of the sample shows the presence of $11 \%$ of companies where the Software and Servicies sector stands out, as $70 \%$ of companies in the sector still use it with a clear distinction from others.

Table 3. Sectors of companies with questionnaire in website

\begin{tabular}{lll}
\hline Industry Group & N. of company with questionnaire in website & \% of Total \\
\hline Banks & 1 & $3,70 \%$ \\
Consumer Durables \& Apparel & 1 & $10,00 \%$ \\
Insurance & 2 & $12,50 \%$ \\
Technology Hardware \& Equipment & 1 & $9,09 \%$ \\
Total & $\mathbf{5}$ & $\mathbf{1 , 5 8 \%}$ \\
\hline
\end{tabular}

Table 4. Sectors of companies with Forum/Blog in website

\begin{tabular}{llc}
\hline Industry Group & N. of company with Forum/Blog in website & \% of Total \\
\hline Automobiles \& Components & 1 & $10,00 \%$ \\
Banks & 4 & $14,81 \%$ \\
Capital Goods & 1 & $3,03 \%$ \\
Commercial \& Professional Services & 1 & $14,29 \%$ \\
Diversified Financials & 1 & $6,67 \%$ \\
Health Care Equipment \& Services & 1 & $8,33 \%$ \\
Materials & 1 & $4,17 \%$ \\
Media & 1 & $16,67 \%$ \\
Pharmaceuticals, Biotechnology \& Life Sciences & 2 & $18,18 \%$ \\
Real Estate & 4 & $20,00 \%$ \\
Retailing & 1 & $10,00 \%$ \\
Software \& Services & 12 & $70,59 \%$ \\
Technology Hardware \& Equipment & 3 & $27,27 \%$ \\
Telecommunication Services & 1 & $11,11 \%$ \\
Utilities & 1 & $6,67 \%$ \\
Total & $\mathbf{3 5}$ & $\mathbf{1 1 , 0 4 \%}$ \\
\hline
\end{tabular}

Finally the last focus in on the use of social media. The analysis of the 316 websites of the DJSI companies shows that $80 \%$ of the sample presents link to one social channel. The $71 \%$ of them have, at least, Twitter (72\%), Linkedin (70\%) and Facebook (67\%). This is more or less shared by all sectors. The chart shows that the lowest peaks of the line were reached in the Semiconductors \& Semiconductor Equipment sector with 33\% and Telecommunications Services with $44 \%$. The other sectors all have a strong proposal to use social media. 


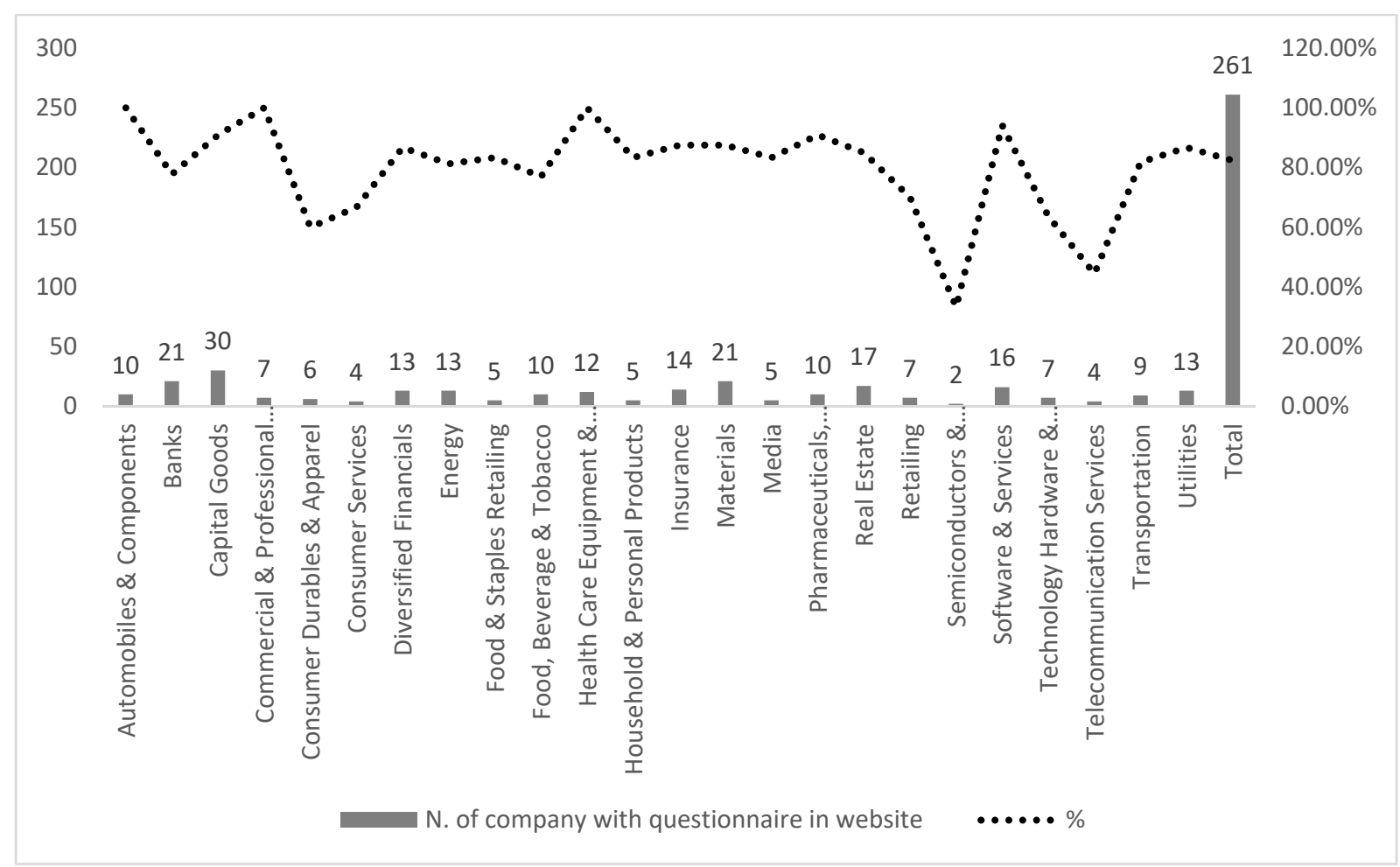

Figure 14. Sectors of companies that used social media

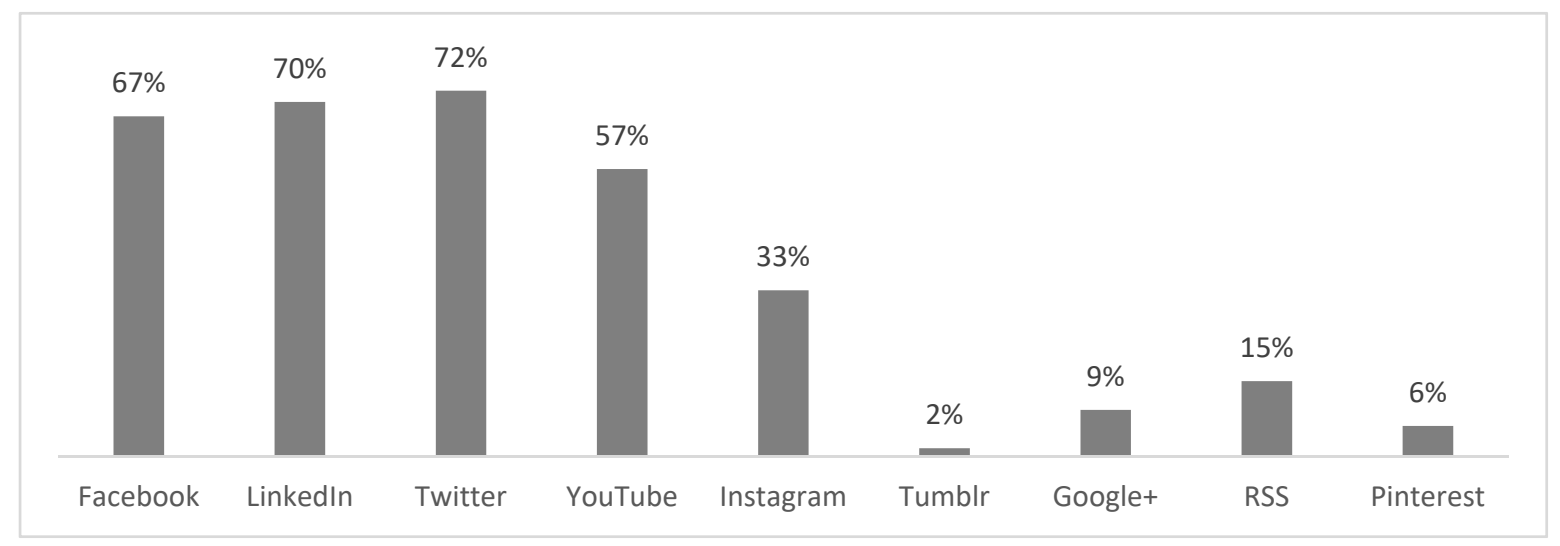

Figure 15. Type of social media

\section{Discussion}

Many authors studied the role of CSR communication based on two key words: transparency and dialogue with stakeholders (Kim, 2014; Kim \& Ferguson, 2018; Seele \& Lock, 2014). This paper investigates the use of the internet-based tools to foster CSR communication by DJSI listed companies. The research questions are: Which method of engagement DJSI companies use? Is the choice of method different between sectors?

This question arises in the light of recent studies focused on Internet-based technologies seen as timely communication tools available to companies that may decide to use to satisfy the increasing demand of stakeholders for transparency on CSR information (Lodhia et al., 2017; Kim, 2019; Moratis \& Brandt, 2017).

As for the first question. The method of engagement is divided into two categories: One-way communication and two-way communication. The results reveal that it wins the first category (CSR section, News and CSR report) as a major diffusion (94\%) in the companies analysed. A strong result is also achieved by the use of social media $(80 \%)$ as bidirectional communication. Result that confirms the claims of other authors (Lodhia et al., 2017; Dunn \& Harness, 2018) on the strong use of social media capable of involving a broad stakeholder group on 
business economic, social and environmental practices and policies. Social media allow companies not only to respond promptly to stakeholders' demands, but also have the ability to "influence" the perception of stakeholders in corporate RSI practices (Adi et al., 2015). Tools such as e-mail/web form have also found a strong diffusion, but such tools rather than allowing an open and interactive speech allow the company to "say, not listen" (Grunig \& Hunt, 1984). In fact, the lack of use of forums and blogs by companies confirm this trend towards unidirectional communication rather than bidirectional. Not to be overlooked are the results on accessibility: A considerable part of DJSI websites (79\%) did not provide information on accessibility, apparently neglecting the opportunity for stakeholders with disabilities to interact with them. A reflection emerges in this regard: If the goal is to involve stakeholders by communicating the company's social commitment, how can it be achieved if the communication tools adopted by the company do not allow everyone access to information? Investing in accessibility by companies is important, bearing in mind that the CSR Communication clearly driven by extrinsic motivations could have a negative impact on stakeholders' judgements (Du et al., 2010).

Regard the second research question. In contrast with the findings suggested by several studies according to which sector specific affects firms' operation and behaviours (Wanderley et al., 2008) and have a significant variability in the type and level of social and environmental information (Brammer \& Pavelin, 2006; Bozzolan, O'Regan \&Ricceri, 2006), the industry sector is not relevant in the present study in fact the influence of companies' sector to the choice of CSR communication tools seems to be marginally relevant.

In the tool-specific analysis there are very few cases where the behaviour of a sector is markedly different from the sample in general. This is the case of the News Section where the average sector uses it at $50 \%$ compared to the $94 \%$ in general declared by the whole sample. The case of the section dedicated to stakeholder engagement in the field of Pharmaceuticals, Biotechnology \& Life Sciences present in only $9 \%$ of the companies in that sector compared to $32 \%$ of the total that declares it. The Insurance sector instead chooses, unlike the companies of other sectors, to use very much $(70 \%)$ forums and blogs as two-way communication tools. Lack of homogeneity between the sample sectors is detected for the use of e-mails and forms where each sector seems to make different choices. About the social media are prevalent used to communicate CSR by companies operating in services sector. The sectors with a higher percentage of social media adherence are the materials and capital goods sectors. This result is in line with what emerges from the literature on the strong propensity to use social media by companies most exposed to negative externalities. Through social media, they try to earn the confidence of stakeholders with high social expectations every day (Adelopo et al., 2012). We can therefore conclude that only in rare cases does the sector of belonging influence the choices of the communication tools used.

\section{Conclusion}

Corporate social responsibility (CSR) has become a frequent topic of discussion and research. Many autors and relevante entities underlined the importance of CSR communication by organizations. In this scenario emerge the importance to engage the stakeholders in dialogue trought the use a variety of method of engagement.

Given the growing attention to CSR communication and stakeholder enagagement this study carried out a complete analysis of all types of internet-based tools, available on the company's website. The contribution to the literature on CSR communication offered by this study concerned the still prevalent use of unidirectional tools by companies with a particular focus on sustainability and also the use of social media. The study also reveals practical implications for professionals and business managers: understanding the criricity related to the use of digital tools of CSR communication (like reputational factor) becomes increasingly important in order to be able to establish dialogue with stakeholders and inform them about the CSR activities of the companies (Pucheta-Martínez et al., 2020). This study has three main limitations: data change speed, language and keywords. The business use of the Web is constantly evolving, over time the results may be different. The study does not examine websites set up in languages other than English. Thirdly, the approach to content analysis could have a limit due to the attention given only to individual words rather than in some cases to the possible analysis of all the narrative content of the tool (Paisey \& Paisey, 2006). For future research about the phenomenon of stakeholder enegagement, it might be useful to understand the perception of engagement methods from the stakeholder perspective so as to understand their perceptions of CSR communication activities.

\section{References}

Adams, C. A., \& Frost, G. R. (2006). The internet and change in corporate stakeholder engagement and communication strategies on social and environmental performance. Journal of Accounting \& Organizational Change, 2(3), 281-303. https://doi.org/10.1108/18325910610690090 
Adelopo, I., Cea Moure, R., Vargas Preciado, L., \& Obalola, M. (2012). Determinants of web-accessibility of corporate social responsibility communications. Journal of Global Responsibility, 3(2), 235-247. https://doi.org/10.1108/20412561211260539

Adi, A., \& Grigore, G. (2015). Communicating CSR on social media: the case of Pfizer's social media communications in Europe. In Corporate social responsibility in the digital age (pp. 143-163). Emerald Group Publishing Limited.

Adi, A., Crowther, D., \& Grigore, G. (Eds.). (2015). Introduction to Corporate Social Responsibility in the Digital Age. In Corporate Social Responsibility in the Digital Age (pp. ix-xvi). Emerald Group Publishing Limited.

Backstrand, K., \& Saward, M. (2004). Democratizing Global Governance: Stakeholder Democracy at the World Summit for Sustainable Development. In American Political Science Association Conference, Chicago.

Basil, D. Z., \& Erlandson, J. (2008). Corporate social responsibility website representations: a longitudinal study of internal and external self-presentations. Journal of Marketing Communications, 14(2), 125-137. https://doi.org/10.1080/13527260701858497

Bochenek, L. M., \& Blili, S. (2014). Social media champions-drivers and sophistication process of social media strategic management. In Social media in strategic management (pp. 143-167). Emerald Group Publishing Limited.

Bonsón, E., \& Ratkai, M. (2013). A set of metrics to assess stakeholder engagement and social legitimacy on a corporate Facebook page. Online Information Review, 37(5), 787-803. https://doi.org/10.1108/OIR-03-2012-0054

Bozzolan, S., O’Regan, P., \& Ricceri, F. (2006). Intellectual capital disclosure: a comparison of Italy and the UK. Journal of Human Resources Costing and Accounting, 10(2), 92-113.

Brammer, S. J., \& Pavelin, S. (2006). Corporate reputation and social performance: The importance of fit. Journal of management studies, 43(3), 435-455.

Chaudhri, V., \& Wang, J. (2007). Communicating corporate social responsibility on the internet: A case study of the top 100 information technology companies in India. Management Communication Quarterly, 21(2), 232-247. https://doi.org/10.1177/0893318907308746

Correa-Garcia, J. A., Garcia-Benau, M. A., \& Garcia-Meca, E. (2018). CSR communication strategies of colombian business groups: An analysis of corporate reports. Sustainability, 10(5), 1602. https://doi.org/10.3390/su10051602

Deegan C. \& Gordon B. (1996). A study of the environmental disclosures practices of Australian corporations. Accounting and Business Research, 26(3), 187-199.

Du, S., Bhattacharya, C. B., \& Sen, S. (2010). Maximizing business returns to corporate social responsibility (CSR): The role of CSR communication. International journal of management reviews, 12(1), 8-19. https://doi.org/10.1111/j.1468-2370.2009.00276.

Dunn, K., \& Harness, D. (2018). Communicating corporate social responsibility in a social world: the effects of company-generated and user-generated social media content on CSR attributions and scepticism. Journal of Marketing Management, 34(17-18), 1503-1529. https://doi.org/10.1080/0267257X.2018.1536675

Esrock, S. L., \& Leichty, G. B. (1998). Social responsibility and corporate web pages: Self-presentation or agenda setting? Public Relations Review, 24(3), 305-319. https://doi.org/10.1016/S0363-8111(99)80142-8

Freeman, R. E. (1984). Strategic Management: A Stakeholder Approach, Prentice-Hall, Englewood Cliffs, NJ.

Frostenson, M., Helin, S., \& Sandström, J. (2011). Organising corporate responsibility communication through filtration: A study of web communication patterns in Swedish retail. Journal of Business Ethics, 100(1), 31-43. https://doi.org/10.1007/s10551-011-0771-7

Gamerschlag, R., Möller, K., \& Verbeeten, F. (2011). Determinants of voluntary CSR disclosure: empirical evidence from Germany. Review of Managerial Science, 5(2-3), 233-262.

Gray, R., \& Guthrie, J. (2007). Social accounting, mega accounting and beyond: a festschrift in honour of M.R. Mathews. St. Andrews: CSEAR Publishing.

Grunig, J. E., \& Hunt, T. T. (1984). Managing Public Relations CL. J. E. Grunig, \& T. Hunt, Managing Public Relations CL. Cengage Learning. 
Guillamón-Saorín, E., \& Martínez-López, F. J. (2013). Corporate financial communication and the internet: manipulating investor audiences? Online Information Review, 37(4), 518-537. https://doi.org/10.1108/OIR-10-2011-0142

Guthrie, J., Cuganesan, S., \& Ward, L. (2008). Disclosure media for social and environmental matters within the Australian food and beverage industry. Social and Environmental Accountability Journal, 28(1), 33-44. https://doi.org/10.1080/0969160X.2008.9651789

Ha, L., \& James, E. L. (1998). Interactivity reexamined: A baseline analysis of early business web sites. Journal of Broadcasting \& Electronic Media, 42(4), 457-474. https://doi.org/10.1080/08838159809364462

Habermas, J. (1990). Moral consciousness and communicative action. MIT press.

Haddock-Fraser, J., \& Tourelle, M. M. (2010). Corporate motivations for environmental sustainable development: exploring the role of consumers in stakeholders engagement. Business Strategy and the Environment, 19, $527-542$

Hahn, R., \& Kühnen, M. (2013). Determinants of sustainability reporting: a review of results, trends, theory, and opportunities in an expanding field of research. Journal of Cleaner Production, 59, 5-21. https://doi.org/10.1016/j.jclepro.2013.07.005

Hawn, O., Chatterji, A. K., \& Mitchell, W. (2018). Do investors actually value sustainability? New evidence from investor reactions to the Dow Jones Sustainability Index (DJSI). Strategic Management Journal, 39(4), 949-976. https://doi.org/10.1002/smj.2752

Hassan, A., \& Ibrahim, E. (2012). Corporate environmental information disclosure: factors influencing companies'success in attaining environmental awards. Corporate Social Responsibility and Environmental Management, 19, 32-46.

Herzig, C., \& Godemann, J. (2010). Internet-supported sustainability reporting: Developments in Germany. Management Research Review, 33(11), 1064-1082. https://doi.org/10.1108/01409171011085903

Jose, A., \& Lee, S. (2007). Environmental reporting of global corporations: A content analysis based on website disclosures. Journal of Business Ethics, 72(4), 307-321. https://doi.org/10.1007/s10551-006-9172-8

Junior, R. M., Best, P. J., \& Cotter, J. (2014). Sustainability reporting and assurance: a historical analysis on a world-wide phenomenon. Journal of Business Ethics, 120(1), 1-11. https://doi.org/10.1007/s10551-013-1637-y

Kim, Y. (2014). Strategic communication of corporate social responsibility (CSR): Effects of stated motives and corporate reputation on stakeholder responses. Public Relations Review, 40(5), 838-840. https://doi.org/10.1016/j.pubrev.2014.07.005

Kim, S., \& Ferguson, M. A. T. (2018). Dimensions of effective CSR communication based on public expectations. Journal of Marketing Communications, 24(6), 549-567. https://doi.org/10.1080/13527266.2015.1118143

Kim, S. (2019). The process model of corporate social responsibility (CSR) communication: CSR communication and its relationship with consumers' CSR knowledge, trust, and corporate reputation perception. Journal of Business Ethics, 154(4), 1143-1159. https://doi.org/10.1007/s10551-017-3433-6

Krippendorff, K. (2018). Content analysis: An introduction to its methodology. Sage publications.

ISO-OECD. (2017). Practical overview of the linkages between ISO 26000:2010, Guidance on social responsibility, and OECD Guidelines for Multinational Enterprises (Version: 7 February 2017)

Li, Z., \& Li, C. (2014). Tweet or "re-tweet"? An experiment of message strategy and interactivity on Twitter. Internet Research, 24(5), 648-667. https://doi.org/10.1108/IntR-11-2013-0233

Lim, J. S., \& Greenwood, C. A. (2017). Communicating corporate social responsibility (CSR): Stakeholder responsiveness and engagement strategy to achieve CSR goals. Public Relations Review, 43(4), 768-776. https://doi.org/10.1016/j.pubrev.2017.06.007

Lodhia, S. (2014). Factors influencing the use of the World Wide Web for sustainability communication: An Australian mining perspective. Journal of Cleaner Production, 84, 142-154. https://doi.org/10.1016/j.jclepro.2014.08.085

Lodhia, S., \& Stone, G. (2017). Integrated reporting in an internet and social media communication environment: conceptual insights. Australian Accounting Review, 27(1), 17-33. https://doi.org/10.1111/auar.12143 
Maier, C. D., \& Ravazzani, S. (2019). Bridging diversity management and CSR in online external communication. Corporate Communications: An International Journal, 24(2), 269-286. https://doi.org/10.1108/CCIJ-01-2018-0015

Moreno, A., \& Capriotti, P. (2009). Communicating CSR, citizenship and sustainability on the web. Journal of Communication Management, 13(2), 157-175. https://doi.org/10.1108/13632540910951768

Morsing, M., \& Schultz, M. (2006). Corporate social responsibility communication: stakeholder information, response and involvement strategies. Business ethics: A European Review, 15(4), 323-338. https://doi.org/10.1111/j.1467-8608.2006.00460.x

Nelson, E. K. (2019). Come on feel the noise: the relationship between stakeholder engagement and viral messaging through an association's Twitter use. International Review on Public and Nonprofit Marketing, 1-19. https://doi.org/10.1007/s12208-019-00219-1

Owen, D. L., Swift, T., \& Hunt, K. (2001). Questioning the role of stakeholder engagement in social and ethical accounting, auditing and reporting. Accounting Forum, 25(3), 264-282. https://doi.org/10.1111/1467-6303.00066

Paisey, C., \& Paisey, N. J. (2006). And They All Lived Happily Ever After? Exploring the Possibilities of Mobilising the Internet to Promote a More Enabling Accounting for Occupational Pension Schemes. $\begin{array}{lllll}\text { Accounting, Auditing } \quad \& \quad \text { Accountability } & \text { Journal, } & 19(5), & \text { 719-758. }\end{array}$ http://dx.doi.org/10.1108/09513570610689677

Patten D. M. (2002). The relation between environmental performance and environmental disclosure: a research note. Accounting, Organizations and Society, 27(8), 763-773.

Pucheta-Martínez, M. C., \& Gallego-Álvarez, I. (2020). Corporate environmental disclosure practices in different national contexts: The influence of cultural dimensions. Organization \& Environment, 33(4), 597-623.

Siano A., Conte F., Amabile S., Vollero A., \& Piciocchi P. (2016). Communicating Sustainability: An Operational Model for Evaluating Corporate Websites. Sustainability, 8(9), 950. https://doi:10.3390/su8090950

Scherer, A. G., \& Palazzo, G. (2007). Toward a political conception of corporate responsibility: Business and society seen from a Habermasian perspective. Academy of Management Review, 32(4), 1096-1120. https://doi.org/10.5465/amr.2007.26585837

Schoeneborn, D., Morsing, M., \& Crane, A. (2020). Formative perspectives on the relation between CSR communication and CSR practices: Pathways for walking, talking, and t (w) alking. Business \& Society, $59(1), 5-33$.

Seele, P., \& Lock, I. (2014). Instrumental and/or deliberative? A typology of CSR communication tools. Journal of Business Ethics. https://doi.org/10.1007/s10551-014-2282-9

Sikka, P. (2006). The internet and possibilities for counter accounts: some reflections. Accounting, Auditing \& Accountability Journal, 19(5), 759-769. https://doi.org/10.1108/09513570610689686

Swift, T. (2001). Trust, reputation and corporate accountability to stakeholders. Business Ethics: A European Review, 10(1), 16-26. https://doi.org/10.1111/1467-8608.00208

Tagesson, T., Blank, V., Broberg, P., \& Collin, S. (2009). What explains the extent and content of social and environmental disclosures on corporate websites: a study of social and environmental reporting in Swedish listed corporations. Corporate Social Responsibility and Environmental Management, 16(6), 352-364. https://doi.org/10.1002/csr.194

Tetrevova, L., Patak, M., \& Kyrylenko, I. (2019). Web-based CSR communication in post-communist countries. Applied Economics Letters, 26(10), 866-871. https://doi.org/10.1080/13504851.2018.1508866

Thomson, I., \& Bebbington, J. (2005). Social and environmental reporting in the UK: a pedagogic evaluation. Critical Perspectives on Accounting, 16(5), 507-533. https://doi.org/10.1016/j.cpa.2003.06.003

Torelli, R., Balluchi, F., \& Furlotti, K. (2020). The materiality assessment and stakeholder engagement: A content analysis of sustainability reports. Corporate Social Responsibility and Environmental Management, 27(2), 470-484.

Unerman, J., \& Bennett, M. (2004). Increased stakeholder dialogue and the internet: towards greater corporate accountability or reinforcing capitalist hegemony? Accounting, Organizations and Society, 29(7), 685-707. 
https://doi.org/10.1016/j.aos.2003.10.009

United Nations. (2011). Guiding principles on business and human rights implementing the United Nations. Retrieved from https://www.ohchr.org/documents/publications/guidingprinciplesbusinesshr_en.pdf

Yekini, K. C., Omoteso, K., \& Adegbite, E. (2019). CSR communication research: a theoretical-cum-methodological perspective from semiotics. Business \& Society. https://doi.org/10.1177/0007650319843623

Young, S., \& Marais, M. (2012). A multi-level perspective of CSR reporting: The implications of national institutions and industry risk characteristics. Corporate Governance: An International Review, 20(5), $432-450$

Wanderley, L. S. O., Lucian, R., Farache, F., \& de Sousa Filho, J. M. (2008). CSR information disclosure on the web: a context-based approach analysing the influence of country of origin and industry sector. Journal of business ethics, 82(2), 369-378. https://doi.org/10.1007/s10551-008-9892-z

Wheeler, D., \& Elkington, J. (2001). The end of the corporate environmental report? Or the advent of cybernetic sustainability reporting and communication. Business Strategy and the Environment, 10(1), 1-14. https://doi.org/10.1002/1099-0836(200101/02)10:1<1::AID-BSE274>3.0.CO;2-0

Williams, S.M., \& Ho Wern Pei, C.A. (1999). Corporate social disclosures by listed companies on their web sites: An international comparison. The International Journal of Accounting, 34(3), 389-419. https://doi.org/10.1016/S0020-7063(99)00016-3

\section{Copyrights}

Copyright for this article is retained by the author(s), with first publication rights granted to the journal.

This is an open-access article distributed under the terms and conditions of the Creative Commons Attribution license (http://creativecommons.org/licenses/by/4.0/). 